\title{
SAGEBRUSH AND SNOWSHOES: THE STRUGGLE FOR NATURAL RESOURGE CONTROL IN THE UNITED STATES AND CANADA
}

\author{
Gretchen E. NAGY
}

Recent years have seen an increasing awareness on the part of all western nations of the need to secure and maintain dependable sources of oil and natural gas to meet the energy needs of industrial economies. ${ }^{1}$ In those countries without domestic supplies, attention is focused upon methods of insuring a steady flow of imported oil and gas. Those countries with domestic supplies have been faced with the different (and in some cases additional) problem of determining how best to manage and control those supplies.

Two countries facing this latter problem are the United States and Canada. Of particular concern has been the issue of whether control of domestic oil and gas development should be centered at the local or national level. In recent years, Canada's oil-rich western provinces have been actively advocating increased provincial authority and a concomitant decrease in federal power. ${ }^{2}$ Concurrently, the oil and gas producing states in the United States have sought greater control over their energy resources. ${ }^{3}$ While in both countries the national government has paid lip service to a continued role for local government, policy pronouncements clearly indicate a climate of continued confrontation. ${ }^{4}$ Each country must deal with this

\section{Copyright (C) 1981 by Law and Contemporary Problems}

1. Oil and natural gas provide more than three-fourths of all energy consumed in the United States. Public Affairs Clearinghouse, Energy: A Guide to Organizations and Information ReSOURCES IN THE UNITED STATES 69 (2d ed. 1978).

2. See, e.g., NEWSWEEK, Sept.22, 1980, at 42; N.Y. Times, Jan. 11, 1981, § 1, at 8 . Indeed some separatist sentiment has cropped up among Albertans and other western Canadians. After the National Energy Program was announced on October 28, 1980, support for the separatists increased dramatically. See generally, Ralph Hedlin Assoc., Westem Canada in Confederation, II D.M.T. MonTHLy NewsletTER, Report 6, at 5-9 (1981).

3. See, e.g., Callison, The Great Sagebrush Rally, 83 NAT'L AudOBON SoC'Y 113 (1981); Conely, The Rape of the West, 167 Outdoor Life 4 (1981); Trueblood, The Sagebrush Ripoff, 85 Field \& STREAM 32 (1981).

4. In 1974, the Federal-Provincial Energy Conference was convened in Canada after the enactment of a flurry of federal and provincial legislation relating to energy resources. For a chart depicting the legislation enacted during this period, see Harrison, Natural Resources and the Constitution: Some Recent Developments and Their Implications for the Future Regulation of Resource Industries, 18 ALTA L. REV. 1, 4 (1980). The Canadian Prime Minister remarked during the Conference that "[w]hile the federal government recognizes the legitimate interests of both provincial governments and private companies, we are determined to safeguard the interests of the consumers of Canada." Opening Statement by the Prime Minister of Canada AT The First Ministers' Conference on Energy, Ottawa, Jan. 22, 1974, Conf. Doc. No. FP.4127, as quoted in Harrison, at 4.

While one commentator noted that former President Carter "impliedly recognized the importance of the gas producing states' roles in regulating new gas, thereby returning to the States a portion of the power that, arguably, had been taken away from them by the Phillips decision," Richard, Appeal from Jarndyce $v$. Jarndyce: The State Role Under the Natural Gas Policy Act of 1978, 41 LA. L. REV. 147, 152 (1980), his 
confrontation within a different constitutional framework. This note will set forth these differing frameworks, and discuss the impact of specific provisions upon the natural resources confrontation. ${ }^{5}$ In particular, the constitutional weapons of each side will be enumerated. It should be noted, however, that policy considerations

National Energy Plan called for legislation to do away with the "[a]rtificial distinction between interstate and intrastate markets." The National Energy Plan, Executive Office of the President, ENergy Policy and Planning 52 (1977). Indeed, under the Natural Gas Policy Act of 1978, 15 U.S.C. \$§ 3301 3432 (NGPA) federal price controls were extended to the intrastate market. See generally, Comment, For Gas Congress Spells Relief N-G-P-A: An Analysis of the Natural Gas Policy Act of 1978, 40 U. PITT. L. REV. 429 (1979).

5. The Canadian constitutional provisions herein discussed are amended to some extent by the proposed constitutional resolution currently being debated in Canada. These amendments, if enacted, would obviously alter this note's discussion of Canadian constitutional law. See Part I infra. The text of the amendments is as follows:

\section{Non-Renewable Natural Resources Forestry Resources and Electrical Energy}

92A. (1) In each province, the legislature may exclusively make laws in relation to

(a) exploration for non-renewable natural resources in the province;

(b) development, conservation and management of non-renewable natural resources and forestry resources in the province, including laws in relation to the rate of primary production therefrom; and

(c) development, conservation and management of sites and facilities in the province for the generation and production of electrical energy.

(2) In each province, the legislature may make laws in relation to the export from the province to another part of Canada of the primary production from non-renewable natural resources and forestry resources in the province and the production from facilities in the province for the generation of electrical energy, but such laws may not authorize or provide for discrimination in prices or in supplies exported to another part of Canada.

(3) Nothing in subsection (1) derogates from the authority of parliament to enact laws in relation to the matters referred to in that subsection and, where such a law of Parliament and a law of a province conflict, the law of Parliament prevails to the extent of the conflict.

(4) In each province, the legislature may make laws in relation to the raising of money by any mode or system of taxation in respect of

(a) non-renewable natural resources and forestry resources in the province and the primary production therefrom, and

(b) sites and facilities in the province for the generation of electrical energy and the production therefrom,

whether or not such production is exported in whole or in part from the province, but such laws may not authorize or provide for taxation that differentiates between production exported to another part of Canada and production not exported from the province.

(5) The expression "primary production" has the meaning assigned by the sixth schedule.

(6) Nothing in subsections (1) to (5) derogates from any powers or rights that a legislature or government of a province had immediately before the coming into force of this section.

\section{The Sixth Schedule \\ Primary Production from Non-Renewable Natural Resources \\ and Forestry Resources}

1. For the purposes of section $92 \mathrm{~A}$ of this Act,

(a) production from non-renewable natural resource is primary production therefrom if

(i) it is in the form in which it exists upon its recovery or severance from its natural state, or

(ii) it is a product resulting from processing or refining the resource, and is not a manufactured product or a product resulting from refining crude oil, refining upgraded heavey crude oil, refining gases or liquids derived from coal or refining a synthetic equivalent of crude oil; and

(b) production from a forestry resource is primary production therefrom if it consists of sawlogs, poles, lumber, woodchips, sawdust or any other primary wood product, or wood pulp, and is not a product manufactured from wood. 
having little to do with broad constitutional guidelines may ultimately decide the issue.

\section{I}

\section{The Canadian Constitution and the Division of Legislative Powers Between the Federal and Provincial \\ GOVERNMENTS}

The Canadian Constitution is embodied, for the most part, in the British North America Act of 1867 (BNA Act). ${ }^{6}$ The most important aspect of the BNA Act is the distribution of lawmaking powers between federal and provincial governments. $^{7}$ Canadian provincial legislatures are not subordinate to the federal Parliament. Rather, they are considered coordinate lawmaking bodies. Thus, a provincial legislature may pass legislation identical to that of Parliament. In case of any incompatibility, the federal provision controls. ${ }^{8}$ Section 91 of the BNA Act gives the federal Parliament the power to "make laws for the Peace, Order, and good government of Canada,"9 and enumerates thirty-one specific powers as illustrations. ${ }^{10}$ Section 92 provides that the provincial legislatures shall have exclusive power to make laws regarding the sixteen subjects listed in that section. ${ }^{11}$ In addition, section 109 reserves jurisdiction over lands, mines, minerals and royalties to the provinces. ${ }^{12}$

\section{A. Federal Authority to Legislate with Respect to Oil and Gas Resources}

The peace, order and good government clause grants the federal government the authority to act in a crisis. ${ }^{13}$ This clause is of primary importance in situations

6. The British North America Act, 1867, 30 \& 31 Vict., c. 3 [hereinafter cited as BNA Act]. The preamble of the BNA Act provides that the Constitution is to be similar in principle to that of the United Kingdom. Thus the Magna Carta, the Petition of Right, the Act of Settlement and the Habeas Corpus Act form part of the Canadian Constitution, as do British customs regarding the administration of government. F. Sussman, THE LAW IN CANADA 15 (1976). The BNA Act is not as broad and far-reaching as the U.S. Constitution. For example, the BNA Act contains no corresponding Bill of Rights. SUSSMAN at 15.

7. SUSSMAN, supra note 6 , at 15.

8. Matas, The EEC as a Model for Canada, 10 MAN. L. J. 259, 269 (1980). The doctrine of paramountcy of federal legislation was clearly articulated in Reference Re Fisheries Act, 1914, 1 D.L.R. 194 (1930). However, the fact that the provisions are concurrent is not in itself a cause for concern. Matas at 272-73.

9. BNA Act, supra note $6, \S 91$.

10. Id. This list of specific powers is not intended to be an exclusive list. Rather, it is meant to illustrate examples of powers that are granted to the federal government under the peace, order and good government clause. SUSSMAN, supra note 6 , at 17 . Some of the powers enumerated in $\S 91$ include: "(2) Regulation of Trade and Commerce; . . . (3) The raising of money by any Mode or System of Taxation."

11. BNA Act, supra note 6. Some of these powers in $\$ 92$ include: “(2) Direct Taxation within the Province in order to the raising of a Revenue for Provincial Purposes; . . . (5) The Management and Sale of the Public Lands belonging to the Province and of the Timber and Wood thereon; . . (10) Local Works and Undertakings other than such as are of the following Classes: (a) Lines of Steam or other Ships, Railways, Canals, Telegraphs, and other Works and Undertakings connecting the Province with any other or others of the Provinces, or extending beyond the limits of the Province; . . . (c) Such works as, although wholly situate within the Province, are before or after their Execution declared by the Parliament of Canada to be for the general Advantage of Canada or for the Advantage of two or more of the Provinces; . . . (16) Generally all matters of a merely local or private Nature in the province."

12. BNA Act, supra note $6, \S 109$.

13. BNA Act, supra note $6, \S 91$. 
which are not otherwise dealt with explicitly in either section 91 or section 92 of the BNA Act. ${ }^{14}$ It is well established that this clause operates during a time of national emergency to grant Parliament the power to legislate with respect to subjects of national concern or interest. ${ }^{15}$ A recent case has indicated that Parliament has broad discretion to find that an emergency exists. In Reference re Anti-Inflation $A c t,{ }^{16}$ the Canadian supreme court accepted without analysis Parliament's judgment that an emergency existed, ${ }^{17}$ thus relaxing the definition of emergency. ${ }^{18}$ The circumstances present in Reference re Anti-Infation Act were substantially similar to those existing in the present oil and gas situation, ${ }^{19}$ and therefore the peace, order and good government clause may provide a constitutional basis for a major increase in federal control over Canada's energy resources. ${ }^{20}$

The trade and commerce clause, which provides that "the exclusive Legislative Authority of the Parliament of Canada extends to all matters coming within. . the Regulation of Trade and Commerce" applies to matters of interprovincial and international trade. ${ }^{21}$ A broad view of the Dominion's trade and commerce power was recently applied by the Supreme Court of Canada in Central

14. Munro v. Nat'l Capital Corp., 57 D.L.R.2d 753 (1966). See generally, Ballem, The Energy Crunch and Constitutional Reform 57 CAN B. REv. 740 (1979); See also, Ballem, Oil and Gas and the Canadian Constitution on Land and Under the Sea, L. Soc'y OF UPPER CaNADA, SPEcial Lectures 251, 252 (1978); Thring, Alberta, Oil, and the Constitution, 17 ALTA. L. REV. 69, 90 (1979).

15. See, e.g., Toronto Elec. Comm'r v. Snider, [1925] A.C. 396 (P.C.) (Can.); Fort Frances Pulp and Power Co. v. Man. Free Press Ltd., [1923] A.C. 695 (P.C.) (Can.); In re Board of Commerce Act, [1922] A.C. 191 (P.C.) (Can.).

16. 68 D.L.R.3d 452 (1976).

17. Reference re Anti-Inflation Act, 68 D.L.R.3d at 497-98. See generally, Ballem, Energy Crunch, supra note 14, at 742; Ballem, Oil and Gas, supra note 14, at 253.

18. The Chief Justice pointed out that the economic crisis imperiled the well-being of the people of Canada as a whole. 68 D.L.R. 3d at 492-97.

19. Ballem, Energy Crunch, supra note 14, at 742. While the court in Reference Re Anti-Inflation Act noted the high rate of inflation in 1974-75, and accepted an economist's statement that "the problem of the coexistence of high unemployment and high inflation rates was not . . . encountered before the late 1960s," the Court also noted that the economist answered the question "Could an economist say that the Canadian economy faced an economic crisis, or was in a critical situation, in October 1975?" in the negative. 68 D.L.R.3d at 496-97. Thus, the economic situation was serious, but apparently not viewed as critical by some economists. The court allowed Parliament's judgment that a crisis existed to stand, without questioning it.

The oil and gas situation has, at times during the 1970 s, been in as serious a state as the economic situation, with rapidly increasing prices and a diminishing supply, even though an economist may be reluctant to say that the situation has actually reached crisis proportions.

20. One author noted that:

[t]he tack taken by the Supreme Court in the Anti-Infation Reference would permit Parliament to deal with an imminent or existing energy crisis by such steps as the establishment of allocation and rationing schemes, fixing prices, and other preventive or remedial measures. On the other hand, the crisis would have to be real and apparent before existing provincial powers could be displaced.

Ballem, Energy Crunch, supra note 14, at 743. Ballem contends further that:

In the absence of any marked change in the present situation the federal government could not rely on the Peace, Order and Good Government clause. Any radical steps by foreign host countries to reduce Canada's supply of crude or increase its price could change this situation overnight.

Ballem, Oil and Gas, supra note 14, at 254. See also, Thring, supra note 14, at 90. "[A]part from a critical national emergency, it is highly unlikely that the courts would allow the expansion of the general powers in matters clearly within section $92 . "$ Id.

21. BNA Act, supra note $6, \S 91(2)$. In addition, an early case held that the trade and commerce power extends to the "general regulation of trade affecting the whole dominion." Citizens Ins. Co. of Canada v. Parsons, 7 App. Cas. 96 (P.C. 1881) (Can.). 
Canada Potash Co. v. Saskatchewan. ${ }^{22}$ The government of Saskatchewan promulgated the Potash Conservation Regulations ${ }^{23}$ to control production and stabilize the price of potash. ${ }^{24}$ These regulations fixed a minimum selling price applicable to permitted production quotas. The only market in which the schemes had any significant effect, however, was the export market. Thus, when Central Canada Potash brought an action challenging the validity of these regulations, they were held to be an impermissible encroachment upon the federal government's trade and commerce power.

With respect to energy resources, the trade and commerce power is the basis for the exercise of federal authority over Canadian oil and gas exports, ${ }^{25}$ as well as over the interprovincial movement of oil and gas. ${ }^{26}$ It is difficult for a province to "legislate with respect to a commodity which is involved in a transaction taking place at least partly outside the province,"27 particularly in light of the supreme court's adoption of the "flow theory" of interprovincial trade. As articulated by Chief Justice Kerash in Reference re The Farm Products Marketing Act, ${ }^{28}$ "Once an article enters into the flow of interprovincial or extraprovincial trade, the subject matter and all its attendant circumstances ceases to be a mere matter of local concern."'29

It is possible that federal legislative authority will be extended to include the processing of oil and gas which is sold outside the producing province, since processing is part of the flow of oil and gas in interprovincial trade. ${ }^{30}$ While the

22. 88 D.L.R.3d 609 (1978).

23. O.C. $1737 / 69$, Sask. Reg. $287 / 69$ as amended by O.C. $404 / 70$, Sask. Reg. $64 / 70$. These regulations were passed under the authority of the Mineral Resources Act, SASK. REV. STAT. ch. 50 (1965).

24. In the Polash case, Chief Justice Laskin noted that the Saskatchewan government had not been acting under proprietary right, but "in pursuance of legislative and statutory authority directed to the proprietary rights of others." 88 D.L.R.3d, at 630 n.1. Thus, the case implies that different considerations would come into play if Saskatchewan has asserted a proprietary right. The assumption is that a province can control its public lands and resources as any private owner can do, but property rights of a province don't immunize the province from federal laws enacted pursuant to the trade and commerce power. Bushnell, Constitutional Law-Proprietary Rights and the Control of Natural Resources, 58 CAN. B. REV. 157, 158 (1980).

25. Ballem, Energy Crunch, supra note 14, at 743. In Caloil Inc. v. Attorney Gen. of Canada, 20 D.L.R. 3d 472 (1971), federal regulations that authorized the National Energy Board to restrict the sale of imported gasoline to certain areas were upheld under the trade and commerce power.

26. Crommelin, Jurisdiction Over Onshore Oil and Gas in Canada, 10 U.B.C.L. REv. 86, 130 (1975). This clause has generally been more successfully used to strike down provincial legislation than as a basis for federal legislation. Thus, this clause is particularly important in the area of oil and gas legislation, since 80 percent of Alberta's and 98 percent of Saskatchewan's crude oil leaves the province for other parts of Canada and the United States. Ballem, Oil and Gas, supra note 14, at 254.

27. Ballem, Oil and Gas, supra note 14, at 256. See generally, Crommelin, supra note 26, at 97-100. One commentator compared the expansion of the trade and commerce power to the broad interpretation of the commerce clause in the U.S. Constitution. Thring, supra note 14, at 89 . For a discussion of the commerce clause as it relates to oil and gas in the United States, see notes 59-62 infra and accompanying text.

28. 7 D.L.R.2d 257 (1957).

29. 7 D.L.R.2d at 265. This "flow of goods" notion was adopted by the court in Attorney Gen. of Man. v. Manitoba Egg and Poultry Ass'n, 19 D.L.R. 3d 169 (S.C.C. 1971), and in Attorney Gen. of Man. v. Burns Foods, Ltd., 40 D.L.R.3d 731 (1975), where legislative schemes to protect domestic produce were held to be primarily related to interprovincial trade, and thus reserved to the federal government under the trade and commerce power. But see Carnation Co. v. Quebec Agri-Marketing Bd., 67 D.L.R.2d 1 (1968), where the flow theory was disregarded.

30. Ballem, Oil and Gas, supra note 14, at 257. Cf. Crommelin, note 26, at 100; Bushnell, supra note 24, at 168 (1980). 
trade and commerce power has not, to date, been extended that far, it is not unlikely that the courts will continue to broaden the scope of this clause, basing the interpretation on the "flow theory".

The taxing power provides the federal government with legislative authority to raise money by any mode or system of taxation. ${ }^{31}$ This power is limited only by section 125 of the BNA Act, which precludes the Dominion from imposing a tax on provincial property. ${ }^{32}$ An unusual interpretation of the limitation in section 125 was set forth in Attomey General of British Columbia v. Attomey General of Canada, ${ }^{33}$ where the Privy Council upheld a federal customs duty on goods imported into a province for sale, even though the goods were provincial property. This decision seems to be based on an interpretation of section 125 which subjects the prohibition of a tax on provincial property to all of the federal government's powers enumerated in section $91 .{ }^{34}$ Since the challenged duty involved a regulation of trade and commerce, expressly reserved to the federal government under section 91(2), the duty was upheld even though it was a tax imposed on provincial property. ${ }^{35}$ The Privy Council's analysis in this case has not been applied to a case concerning federal taxation of oil and gas belonging to the provinces, and it is doubtful that it will be so extended. ${ }^{36}$

The federal government's declaratory power provides an opportunity for unilateral extension of federal jurisdiction. Under section 92(10)(c) of the BNA Act, jurisdiction over "such Works as, although wholly situate within the Province, are before or after their execution decided by the Parliament of Canada to be for the general advantage of Canada or for the Advantage of Two or more of the Provinces" is removed from the provinces. This section "confers upon Parliament an extraordinary power to unilaterally enlarge its jurisdiction." 37 The judgment of

31. BNA Act, supra note $6, \S 91(3)$.

32. BNA Act, supra note $6, \S 125$.

33. (Liquor Import case), [1924] A.C. 222 (P.C.)(Can.).

34. Id. at 225 .

35. As one author noted, "the case does not go so far as to say that all federal customs duties are validly imposed. There remains the question whether the legislation levying the duties is in relation to a matter coming within one of the classes of subjects in section 91." Crommelin, supra note 26, at 107. Furthermore, courts have generally held that the federal government may not use the taxing power to regulate indirectly where it may not regulate directly. See, e.g., In re Insurance Act of Canada, [1932] A.C. 41, 52 (P.C.)(Can.); Attorney Gen. of Canada v. Attorney Gen. of Ontario (Employment and Social Insurance Reference) [1957] A.C. 355 (P.C.)(Can.).

36. "It may be doubted whether [this case] is correct in principle." Crommelin, supra note 26, at 108. Thus, its precedential value is uncertain. The more pressing issue in the area of taxation of oil and gas involves the scope of provincial taxing power. For a discussion of the provincial taxing power, see notes 55 65 infra and accompanying text.

37. Ballem, Energy Crunch, supra note 14, at 745. The declaratory power is described in Reference re Waters and Waters-Powers, 2 D.L.R. 481 (1929) as follows:

The authority created by s. $92(10$ (c) is of a most unusual nature. It is an authority given to the Dominion Parliament to clothe itself with jurisdiction-exclusive jurisdiction-in respect of subjects over which, in the absence of such action by Parliament, exclusive control is, and would remain, vested in the provinces. Parliament is empowered to withdraw from that control matters coming within such subjects and to assume jurisdiction itself. It wields an authority which enables it, in effect, to rearrange the distribution of legislative powers effected directly by the Act, and, in some views of the enactment, to bring about change of the most radical import, in that distribution.

Id. at 220. As of 1977, there have been 470 such declarations made by Parliament. Hogg, ConstituTIONAL LAW OF CANADA 330 (1977). 
Parliament concerning "general advantage" or "advantage of two or more of the provinces" cannot be questioned by the courts when such a declaration is made; the only issue is whether the subject matter of the declaration is a "Work". ${ }^{38}$ It is a generally accepted propostion that oil and gas wells, oil sands plants and processing plants are "Works".39 This would enable Parliament to "declare such facilities to be for the general advantage of Canada and thereby obtain a large measure of control over the oil industry."40 Until Parliament makes such a declaration in the oil and gas field, however, the scope of Parliament's authority under section 92(10)(c) remains undefined. ${ }^{41}$

\section{B. Provincial Legislative Authority with Regard to Oil and Gas}

One source of provincial control of oil and gas resources is direct ownership. ${ }^{42}$ Provincial government ownership, however, is restricted to those resources found on public land held by the province. ${ }^{43}$ The distribution of public land between the federal government and the provinces is set forth in the BNA Act as well as in additional pieces of legislation. ${ }^{44}$ Generally, oil and gas resources on public lands that have not been specifically reserved to the federal government are "vested in the Crown in the right of the province concerned, and are subject to provincial legislative and executive action." 45 As the owner of oil and gas resources, the province has the same rights as any other private property owner, and is subject to the same restrictions on private ownership imposed by common law or legislation. ${ }^{46}$ 1. Legislative Authority of the Provinces Derived From the BNA Act. A province is empowered to make laws relating to "the Management and Sale of the Public Lands belonging to the Province."47 It would appear that oil and gas resources are included within the scope of this action. ${ }^{48}$ Although the exact meaning of "manage-

38. Ballem, Energy Crunch, supra note 14, at 746; Ballem, Oil and Gas, supra note 14, at 261.

39. Ballem, Energy Crunch, supra note 14, at 261.

40. Such a declaration, however, would almost certainly include not only the physical structure of the oil and gas facilities, but also the activities carried on in these facilities. See, e.g. The Queen v. Thumlert, 20 D.L.R. 2d 335 (1960); Montreal v. Montreal Street R. Co., [1922] A.C. 33.

41. Ballem, Energy Crunch, supra note 14, at 261.

42. Crommelin, supra note 26 , at 88 .

43. Id. at 92. Public ownership of onshore oil and gas rights in Ontario, Quebec and the eastern provinces is insubstantial, while in the western provinces most of the oil and gas rights are publicly owned. For example, in British Columbia 90 percent of the mineral rights in the Peace River Block are publicly owned, while in Alberta and Saskatchewan 80 percent of the minerals are on public lands. Id. at 92 .

44. The distribution for Nova Scotia, New Brunswick, Ontario and Quebec is set forth in the BNA Act at $\S \S 108,109$, and 117. Public land was similarly donated in British Columbia when it was added to Canada in 1871 . Crommelin, supra note 26 , at 90 . In the prairie provinces, however, public property rights were not allocated until 1930, British North America Act, 1930, 21 Geo. 5, c. 26 (Imp.).

45. Crommelin, supra note 26 , at 91 .

46. Id. at 93 . The provinces are not restricted by the division of legislative authority set forth in $\$ \$ 91$ and 92 of the BNA Act. Id. at 95. In Smylie v. The Queen, 27 Ont. App. 172 (1900), Associate Justice Moss explained this aspect of publicly owned property in dicta. "I see no reason for thinking that the legislature may not, in respect of his property, viz., attach to the contract a condition not impossible of performance, or unlawful per se, or prohibited by an existing law."

47. BNA Act, supra note $6, \S 92(5)$.

48. See generally, Crommelin, supra note 26, at 101-02. E.g., in Burrard, Power Co., v. The King, [1911] A.C. 87 (P.C.)(Can.), "public lands" were held to include "the water rights incidental to those lands." In addition, the Fisheries case, Attorney Gen. of Canada v. Attorney Gen. of Ont. [1898] A.C. 700 (P.C.)(Can.), held that "public lands" in $\$ 92$ (5) include fishing rights. 
ment and sale" is uncertain, ${ }^{49}$ under this clause, the provincial government is free to choose methods of exploration for ${ }^{50}$ and to regulate production of ${ }^{51}$ Crown oil and gas. Legislation imposing royalties on oil and gas is also within provincial authority as part of the "management and sale of public lands."52 Once title to property has passed from the province, however, this section no longer provides a basis for legislative authority over the property. ${ }^{53}$ Furthermore, management of public lands may effect interprovincial trade and thus conflict with the federal government's trade and commerce power. ${ }^{54}$

Section 92(3) of the BNA Act gives the provincial legislatures authority to levy taxes within a province. ${ }^{55}$ This authority, however, is limited to direct taxation. ${ }^{56}$ Furthermore, the provincial taxing authority is restricted to matters within "the raising of a revenue for provincial purposes." 57

The limitations of "raising revenue for provincial purposes" were examined in Canadian Industrial Gas $\mathcal{G}^{\circ}$ Oil, Lid. v. Govermment of Saskatchewan. ${ }^{58}$ In 1973, the Saskatchewan legislature passed the Oil and Gas Conservation, Stabilization, and Development Act, ${ }^{59}$ designed to divert some of the enhanced value of Saskatchewan

49. Crommelin, supra note 26, at 102-06. There is a line of cases holding that federal legislation which is otherwise valid will not be struck down merely because the subject matter of the legislation is provincial property. See, e.g., The Queen v. Robertson, 6 Can. S. Ct. 52 (1882) (fisheries); Attorney Gen. of B.C. v. Attorney Gen. of Canada, [1914] A.C. 153 (P.C.)(Can.) (fisheries); Ontario Mining Co. v. Seybold, [1903] A.C. 73 (P.C.) (Can.) (mining rights); Attorney Gen. of Canada v. Ontario, [1898] A.C. 700 (P.C.) (Can.) (fisheries); Cushing v. Dupuy, 5 App. Cas. 409 (P.C. 1880) (Can.) (fisheries).

50. Crommelin, supra note 26 , at 122 .

51. Id. at 123 .

52. Id. at 118 .

53. Many provincial legislatures have used this section as a basis for regulating prices of oil and gas, however.

54. The only case in which the relationship between "the management and sale of the public lands belonging to the province" and "the regulation of trade and commerce" was directly at issue was Smylie v. The Queen, 27 Ont. App. 172 (1900). A provincial statute requiring crown timber licenses to include a restrictive condition was upheld as an exercise of provincial legislative authority under the management and sale clause even though the condition might affect trade and commerce. Thus, the Smylie case gave $\S 92(5)$ a broader scope than did the earlier fisheries cases. As Crommelin notes, however, this case also stands for the basic principle that the general must yield to the particular. Crommelin, supra note 26, at 106. It is probable that a provincial statute inserting conditions in sales of oil and gas rights woud be upheld if pursuant to the management and sale of public lands. Id. at 118 .

55. BNA Act, supra note $6, \S 92(3)$. If the thing or person being taxed is within the Province, however, a tax based on some extraprovincial attributes is valid. Crommelin, supro note 26, at 110.

56. In Bank of Toronto v. Lambe, 12 App. Cas. 575 (P.C. 1887)(Can.), the Privy Council adapted John Stuart Mill's definition of direct and indirect taxation:

Taxes are either direct or indirect. A direct tax is one which is demanded from the very person who it is intended or desired should pay it. Indirect taxes are those which are demanded from one person in the expectation and intention that he shall indemnify himself in the expense of another; such are the excise or customs.

Id. at 582. See also Atlantic Smoke Shops, Ltd. v. Conlon and Attorney Gen. of Canada [1943] A.C. 550 (P.C.)(Can.) (direct tax imposed on final consumers of goods); Lawson v. Interior Tree, Fruit and Vegetable Committee, 2 D.L.R. 193 (1931) (indirect tax on intermediate transactions in production or distribution of goods); The King v. Caledonian Collieries, Ltd. [1928] A.C. 358 (P.C.)(Can.) (indirect tax based on gross value of production from a mine); Nickel Rim Mines, Ltd. v. Attorney Gen. of Ont. 53 D.L.R.2d 290 (Ont. 1965), appeal dismissed, 60 D.L.R.2d 576 (1967) (direct tax on net revenue from mining).

57. BNA Act., supra note $6, \S 92(2)$. This section has not been narrowly construed by the courts. Crommelin, supra note 26 , at $110-11$.

58. 80 D.L.R.3d 449 (1978).

59. The Oil and Gas Conservation, Stabilization, and Development Act, 1973, S.S. 1973-73, c. 72, 
oil to the people of Saskatchewan. ${ }^{60}$ Canadian Industrial Gas Oil Ltd. (CIGOL) brought an action against Saskatchewan challenging the constitutionality of the legislation on the grounds that the legislation imposed an impermissible indirect tax and interefered with the federal government's trade and commerce power. The Canadian Supreme Court found the provisions creating a mineral income $\operatorname{tax}^{61}$ and a royalty surcharge ${ }^{62}$ to be ultra vires the legislature. ${ }^{63}$

In concluding that the statute was unconstitutional because it attempted to regulate trade and commerce by fixing prices in the external market, the majority clearly extended the scope of the federal trade and commerce power. ${ }^{64}$ It is clear from the CIGOL decision that a provincial government cannot impose a tax on an export commodity if the effect of the tax is to fix a floor price for the commodity. The decision suggests that the legislation may be held unconstitutional if it attempts to do indirectly what cannot be done directly. ${ }^{65}$

The provinces have exclusive legislative authority over "all matters of a merely local or private Nature in the Province"66 as well as over "Property . . . in the Province". ${ }^{67}$ Legislation regulating the exploration of private oil and gas in the provinces is within the purview of these clauses, absent a contrary Parliamentary declaration. ${ }^{68}$ For example, Alberta may fix the price of gas consumed and pro-

amended S.S. 1973-74, c. 73; amendments to the Mineral Resources Act, S.S. 1973-74, c. 64; and amendments to The Petroleum and Natural Gas Regulations, 1969, O/C 95/74 and 1238/74.

60. Douglas, Canadian Industrial Gas and Oil, Ltd. v. The Govemment of Saskatchewan, 43 SASK. L. REV. 177 (1978-79).

61. The tax was $100 \%$ of the difference between the price received at the well head and the basic well head price, a statutory figure approximately equal to the price per barrel received by producers prior to the energy crisis. The owner's interest in oil and gas rights in producing tracts of less than 1,280 acres were exempted from the tax. Deductions approved by the Minister of Mineral Resources were allowed in respect of increases in production costs and extraordinary transporation costs. Provision was made for the Minister to determine the well head value of the oil where he was of the opinion that oil had been disposed of at less than its fair value.

J. Martland in CIGOL, 80 D.L.R.3d at 449, 451 (1978).

62. (A)ll petroleum and natural gas in all producing tracts within the Province were expropriated and subjected to what was called a 'royalty surcharge'. Oil and gas rights owned by one person in producing tracts not exceeding 1,280 acres were exempted. Although introduced by [r]egulation rather than statute, the royalty surcharge is calculated in the same manner as the mineral income tax. For all practical purposes they are the same, save one exception. The well-head value for the purposes of royalty surcharge is the higher of the price received at the well-head and the price per barrel listed in the Minister's Order.

Id. at 451-52.

63. Id. at 477. The majority and dissent agreed that the mineral income tax was "not an income tax in any generally recognized sense of the term." (Dickson, J.; dissenting opinion.) In addition, the royalty had more characteristics of a tax than of a conventional royalty, since the royalties could not be deducted from income, but were calculated according to fair market value of production. Thus, the court held that the taxation scheme did not constitute direct taxation within the province and was therefore outside the scope of the provincial taxing power under $\$ 92(2)$ of the BNA Act. 80 D.L.R.3d at 463.

A second ground of CIGOL's attack was that the legislation related to trade and commerce which is within the exclusive jurisdiction of Parliament. The majority concluded that the statute did aim at the regulation of trade and commerce, and was thus unconstitutional.

64. Douglas, supra note 60 , at 188 . As one author noted, “. . . the Supreme Court, in broadening the scope of the trade and commerce power, would appear to be moving toward a more centralized view of Canadian federalism particularly in relation to natural resources." Note, The Oil Well Income Tax Act: 1978 43 SASK. L. REV. 125, 129 (1978-79).

65. See generally Elliott, Jurisdictional Dilemmas in Resource Industries, 17 ALTA L. REV. 91, 99-101 (1979).

66. BNA Act, supra note $6, \S 92(16)$.

67. Id. $\$ 92(13)$.

68. Crommelin, supra note 26 , at 123 . Parliament could make a declaration regarding oil and gas 
duced in Alberta. ${ }^{69}$

Section 92(10) grants the provinces exclusive legislative authority over local works and undertakings except those enumerated in subsections (a), (b) and (c), which may be the subject of federal legislation under Parliament's declaratory power. ${ }^{70}$ For example, the interprovincial pipelines are clearly "works and undertakings connecting the province with any other or others of the provinces, or extending beyond the limits of the province," 71 and are consequently subject to federal jurisdiction. ${ }^{72}$ Conversely, feeder and gathering lines that carry oil and gas from producing fields to consumption points within the same province are local works and undertakings and are thus subject to provincial legialative authority. ${ }^{73}$

\section{II}

\section{The U.S. Constitution and the Division of Legislative PoWers between the Federal and State \\ GOVERNMENTS}

The U.S. Constitution provides a federal system that ensures the individual states some autonomy and, at the same time, allots the national government sufficient authority to resolve issues of general concern. ${ }^{74}$ Certain enumerated powers are delegated to the federal government by the states; powers not so delegated are reserved to the states. ${ }^{75}$ The extent of the delegated powers has long been a source

production facilities under $\S 92(10)$ (c) of the BNA Act, taking the regulation of production out of provincial legislative authority. For a discussion of the declaratory power of Parliament, see notes $37-41$ supra and accompanying text.

69. Ballem, Energy Cnunch, supra note 14, at 754. However, where the federal Petroleum Administration Act, S.C. 1974-75, c. 47, applies Alberta may not fix the price of such gas.

70. BNA Act, supra note $6, \S 92(10)$.

71. Id. at $\$ 92(10)(\mathrm{a})$.

72. Crommelin, supra note 26 , at 128 . The National Energy Board has accorded a very broad definition to pipeline:

'Pipeline' means a line for the transmission of gas or oil connecting a province with any other or others of the provinces or extending beyond the limits of a province, and includes all branches, extensions, tanks, reservoirs, storage facilities, pumps, racks, compressors, loading facilitities, interstation systems of communication by telephone, telegraph, or radio, and real and personal property and works connected therewith.

R.S.C. 1970, C. N-61 (as amended by R.S.C. 1970, c. 10 and c. 27 (1st Supp.), and S.C. 1973 (1st Sess.), c. $52, s$. 2. The Dominion has, however, exercised its jurisdiction mainly over trunklines connecting the provinces with one another. Crommelin, supra note 26 , at 128.

73. Crommelin, supra note 26, at 128 . For example, Alberta has placed its feeder and gathering lines under the jurisdiction of the Energy Resources Conservation Board. Id. at 128.

74. Note, Constitutional Law-The Federal System-Siate Sovereignty as an Implied Restraint Upon the Commerce Power-National League of Cities v. Usery, 426 U.S. 833 (1976), 52 WASH. L. REv. 747. One commentator has noted that:

[There are] twin poles of federalism: sufficient national supremacy to preserve unity, and adequate autonomy to prevent centralization. From these standards, other constitutional guideposts follow: an inviolable sovereignty of the states serving to check national aggrandizement, supreme plenary enumerated powers dominating local concerns to serve the general interest, the insulation of "indispensable" state functions from "drastic invasions" by federal power; a national supremacy overcoming state activities burdening by their effect national areas of power.

Salmon, The Federalist Principle: The Interaction of the Commerce Clause and the Tenth Amendment in the Clean Air Act, 2 COL. J. ENviR. L. 290, 359-60 (1976).

75. The tenth amendment provides that " $[\mathrm{t}]$ he powers not delegated to the United States by the Constitution, nor prohibited by it to the States, are reserved to the States respectively, or to the people." In 
of considerable controversy.

\section{A. Federal Legislative Authority with Respect to Oil and Gas}

1. Legislative Authority Over Federally Owned Resources. The federal government has legislative and regulatory power to control production and exploration of federally owned energy resources. The Constitution gives the federal government the power "to dispose of and make all needful Rules and Regulations" over such resources. ${ }^{76}$ Federally owned resources consist of those found under federal land ${ }^{77}$ and those resources reserved under privately owned land. ${ }^{78}$ This is an important power since the federal government owns an estimated 60 percent of the crude oil and natural gas reserves and 80 percent of the oil shale reserves in the United States. ${ }^{79}$

2. Federal Legislative Authority Under the Commerce Clause. Much of the federal government's authority to regulate energy resources is implied from the commerce clause, ${ }^{80}$ which gives Congress the power "to regulate Commerce with foreign Nations, and among the several States." The passage of oil and gas from one state to another is clearly subject to federal legislative authority under the commerce clause, as is the exportation of oil and gas. ${ }^{81}$ The Supreme Court's interpretation of the commerce clause since the late 1930s has broadened the scope of the clause. Federal legislation will generally be upheld if the relationship between the regulation and commerce has a rational basis. ${ }^{82}$

Oklahoma v. Federal Energy Regulatory Commission ${ }^{83}$ was an action brought by four

McCulloch v. Maryland, 17 U.S. (4 Wheat.) 316, 405 (1819), Chief Justice Marshall stated, "This government is acknowledged by all to be one of enumerated powers."

76. U.S. Const., art. IV, $\S 3$, cl.2.

77. Congress has virtually unlimited power to control and dispose of such land. Kleppe v. New Mexico, 426 U.S. 529 (1976); United States v. San Francisco, 310 U.S. 16 (1940). In the absence of Congressional preemption, however, states may exercise their police power over federal lands. In Texas Oil \& Gas Corp. v. Phillips Petroleum Co., 277 F. Supp. 366, (W.D.Okla. 1967), affd per curiam, 406 F.2d 1303 (10th Cir. 1969), cert. denied, 396 U.S. 289 (1969), the district court stated that:

[T] he authorities treating with the matter of exclusive control of federal lands by the Federal Government clearly and definitely hold that State law and the State police power extends over the federal public domain unless and until Congress has determined to deal exclusively with the subject.

277 F. Supp. at 369. For a discussion of federal-state conflicts over control of public lands, S\%e Harvey, Federal-State Relationships in Federal Land and Resources Management, 54 DENVER L. J. 585, $593-98$ (1977).

The federal government operates leasing programs with respect to much of its land, and as lessor controls the terms of the leases. In 1974, the U.S. Department of Interior began a leasing program in the Picenance Basin, where most of the federal government's oil shale reserves are located. The Picenance Basin is located in Colorado, Utah and Wyoming. Id. at 591.

78. Id. at 588-89.

79. Id. at 588 .

80. U.S. Const. art. $1, \$ 8$, cl. 3 .

81. Cf. discussion of the Canadian Parliament's trade and commerce power, at notes 21-30 supra and accompanying text.

82. See generally, J. Nowak, R. Rotunda \& J. Young, Constrtutional Law 150-63 (1978) [hereinafter cited as NOWAK]. An activity comes under the commerce power if it has a close relationship with or effect on commerce. Furthermore, Congress may regulate activities in a single state if the regulation is "necessary and proper" to regulating commerce. Thus, in Phillips Petroleum Co. v. Wisconsin, 347 U.S. 672 (1954), the Court upheld the regulations under the Natural Gas Act that affected interstate aspects of the natural gas industry.

83. 494 F. Supp. 636 (W.D. Okla. 1980). 
gas producing states ${ }^{84}$ challenging the constitutionality of the Natural Gas Policy Act (NGPA). ${ }^{85}$ The plaintiffs alleged that the NGPA exceeded the power of Congress to regulate interstate commerce, and interfered with traditional functions of states, and was therefore impermissible by virtue of the tenth amendment. ${ }^{86}$ In upholding the constitutionality of the NGPA, the district court stated that "[i]t is now beyond argument that Congress may regulate activities which are wholly intrastate when the intrastate activity either has substantial economic effect on interstate commerce or where federal regulation of the intrastate activity is necessary to effectuate interstate regulation." 87 Thus, the court found that Congress "had a rational basis for determining that the unregulated intrastate gas market affected interstate commerce," and that "the means selected by Congress were reasonably adapted to eliminating the burden." 88

3. The Federal Taxing Power. The Constitution expressly provides Congress with broad powers of taxation. ${ }^{89}$ It also provides for intergovernmental immunity with respect to taxation. ${ }^{90}$ Congress may constitutionally levy a tax that incidentally affects a state provided the source of revenue is not uniquely the state's. ${ }^{91}$ Since the federal taxing power is so broad, issues that will arise with respect to taxation in the oil and gas field will most likely concern limits on the taxing power of a state.

\section{B. State Taxes and the Constitution}

States have a broad range of powers to regulate energy resources. Taxation is often used by states as a means of regulating oil and gas. ${ }^{92}$ State taxes which increase production, transportation, or selling costs may be attacked under both the commerce and equal protection clauses.

1. State Property and Income Taxes. The states have the power to levy ad valorem property taxes on real property as well as tangible and intangible personal prop-

84. The four states were Oklahoma, Texas, Louisiana and Wyoming.

85. See note 4 supra

86. 494 F. Supp. at 653.

87. Id.

88. Id. at 654 . The court also stated that:

the Court finds the NGPA to be constitutional. This decision does not find the Act to be wise or fair or best suited to meet the present and future economic and energy needs of the nation. But it is fundamental that establishment of policy in these respects is the business of the elected legislative branch-the Congress. As long as the laws enacted are within its constitutional authority the Courts are not empowered to re-write, or veto them, or to second-guess or otherwise undo its chosen policy despite possible errors of judgment.

Id. at 662 .

89. U.S. Const. art. I, $\S 2$, cl. 3; U.S. ConsT. art. I, $\$ 8$, cl. 1; U.S. Const. art. I, § 9, cl. 4-5; U.S. ConsT. Amend. XVI.

90. New York v. United States, 326 U.S. 572, 576 (1946). For a general discussion of intergovernmental immunity from taxation, See NowAK, supra note 82, at 367-70.

91. New York v. United States, 326 U.S. at 582.

92. Note, The Effect and Validity of State Taxation of Energy Resources, 58 WASH. U. L. Q. 345, 346 (1980). Energy producing states have several objectives in taxing energy resources, including controlling production, compensating for loss of state wealth and compensating for environmental damage. M. WILLRICH, Administration of ENERgy SHORTAges (1976). 
erty. ${ }^{93}$ Real and tangible personal property may be taxed only in the state in which the property is located. Intangible personal property, on the other hand, may be taxed in both the state in which the owner lives and in any state in which the property receives benefits and protection. ${ }^{94}$ Once goods enter the stream of interstate or foreign commerce, however, they become immune from state and local taxation so long as the goods remain in the stream of commerce. ${ }^{95}$

A state may also impose an income tax on all items of income realized by individuals domiciled in the state. Since individuals receive personal benefits from the state, such a tax is deemed to satisfy due process requirements. ${ }^{96}$ Since the state protects a nonresident's business and property, it may also impose an income tax upon the nonresident's income produced in that state. ${ }^{97}$

2. State License Fees. License fees imposed by states will generally be upheld if there is a sufficient nexus between the taxing state and the taxable activity, and if the tax does not unduly burden interstate commerce. ${ }^{98}$ States levy a variety of license fees. Fixed fee licenses will be upheld if the business subjected to the tax is essentially local in nature. ${ }^{99}$ License taxes based on production are generally valid if imposed by the state where production occurs. ${ }^{100}$ License taxes measured by

93. See generally, NowAK, supra note 82 , at 282-304.

94. Thus, the requirements of substantive due process are met if the taxing jurisdiction has provided benefits to the taxpayer or to his property. In Wisconsin v. J.C. Penney Co., 311 U.S. 435, 444-45 (1940), Justice Frankfurter writing for the Court stated that:

[The due process] . . . test is whether property was taken without due process of law or, if paraphrase we must, whether the taxing power exerted by the state bears fiscal relation to protection, opportunities and benefits given by the state. The simple but controlling question is whether the state has given anything for which it can ask return. The substantial privilege of carrying on business in Wisconsin, which has here been given, clearly supports the tax.

95. Goods are deemed to have entered the stream of commerce when the goods physically enter the transit system. Thus, in Coe v. Town of Errol, 116 U.S. 517 (1886), the court sustained a state property tax on logs being held ready for shipment. The Court stated that:

[s] uch goods do not cease to be part of the general mass of property in the state, subject as such, to its jurisdiction, and to taxation in the usual way, until they have been shipped, or entered with a common carrier for transportation, to another state, or have been started upon such transportation in a continuous route or journey. We think that this must be the true rule on the subject.

Coe v. Town of Errol, 116 U.S. at 527.

96. E.g., New York ex rel. Cohn v. Graves, 300 U.S. 308 (1937) (upholding a state tax imposed on residents on rental and interest income derived from property located outside the state); Maguire v. Trefry, 253 U.S. 12 (1920) (upholding a state tax imposed on a resident beneficiary of an out-of-state trust).

97. E.g., Shaffer v. Carter, 252 U.S. 37 (1920) (upholding a state tax imposed on income derived from property or business in the taxing state owned by nonresidents). It is important to note that states are limited in levying taxes by not only the due process clause but also by the privileges and immunities clause. See note text accompanying 113 infra.

In order to avoid unfair tax burdens on multistate corporations, state income tax statutes ususally provide for allocation of certain types of income to various states. See generally, NowAK, supra note 82, at 326-29. See also the Uniform Division of Income for Tax Purposes Act \$\$ 4-8.

98. See Complete Auto Transit, Inc. v. Brady, 430 U.S. 274 (1977) (upholding Mississippi statute assessing a privilege tax upon interstate transporation corporations).

99. E.g., California v. Thompson, 313 U.S. 109 (1941) (upholding a fixed fee license required for selling transportation on public highway in the state). Cf. Robbins v. Taxing Dist., 120 U.S. 489 (1887) (invalidating a fixed fee license tax imposed on salesman who did not maintain a regular place of business in the taxing district).

100. See Oliver Iron Mining Co. v. Lord, 262 U.S. 172 (1923) (upholding a state tax based on a certain percentage of the entire value of ore mined or produced during the year characterizing mining a a local business). 
gross receipts and imposed by the marketplace state may be challenged on the ground that no sufficient nexus exists between the taxable activity and the taxing state. However, the Court has generally sustained the validity of taxes measured by gross receipts imposed by the state of production. ${ }^{101}$

3. State Taxes and Intergovemmental Immunity. Intergovernmental immunity may operate to restrict the taxing power of states as well. Federal activities are generally immune from state taxation, however, states are sometimes able to collect revenues by indirect means. ${ }^{102}$ For example, states may impose a tax on the removal of minerals from lands leased from the federal government. ${ }^{103}$

\section{Constitutional Limits on State Authority}

1. The Commerce Clause and Burdens on Interstate Commerce. While the federal government was increasing its control over intrastate gas and promulgating complex regulations regarding oil, some states were attempting to control their energy resources through taxation. The commerce clause can limit a state's use of the taxing power. The crucial factor is whether the activity burdens interstate commerce. ${ }^{104}$ For example, Montana's severance tax on coal ${ }^{105}$ was recently upheld, despite a challenge to its constitutionality based on the commerce clause and the supremacy clause. ${ }^{106}$ Because the tax is computed at the same rate regardless of the destination, and is calculated according to coal consumed, the Court found

101. E.g., Hope Natural Gas Co. v. Hall, 274 U.S. 284 (1927) (upholding a state tax on business of producing natural gas in state computed on a basis of gross proceeds); American Mfg. Co. v. St. Louis, 250 U.S. 459 (1919) (upholding a city gross receipts tax imposed on every manufacturer doing business in the city). See generally, Hellerstein, State Taxation of Interstate Business and the Supreme Court, 1974 Term: Standard Pressed Steel and Colonial Pipeline, 62 VA. L. REV. 149 (1976). Gross receipts taxes imposed on interstate activities must specify a taxable subject of activity, such as manufacturing. A tax imposed on gross receipts from all trades or businesses will be invalidated as a burden on interstate commerce. See, e.g., J.D. Adams Mfg. v. Storen, 304 U.S. 307 (1938) (invalidating a general gross receipts tax as applied to a firm engaged in interstate commerce).

102. Carver, Intergovermental Relations and Energy Taxation, 58 DENVER L. J. 141, 143 (1980). The Tennessee Valley Authority, for example, is expressly exempt from state taxes, but it can make payments in lieu of taxes on its facilities. 16 U.S.C. $\$ 8311$ (1976).

103. E.g., Montana Coal Severance Tax, MONT. Rev. Codes ANN. $\$ \S 15-35-101$ to -111 (1979). The validity of this tax was recently upheld by the Supreme Court. Commonwealth Edison Co. v. Montana, 49 U.S.L.W. 4957 (1981). See notes 105-107 infra and accompanying text.

104. Cases upholding regulations include Brotherhood of Locomotive Firemen \& Engineers v. Chicago, Rock Island \& Pac. R. R., 393 U.S. 129 (1968), reh. denied, 393 U.S. 1045 (upholding state law requiring full train crews); Cities Serv. Gas Co. v. Peerless Oil \& Gas Co., 340 U.S. 179 (1950) (upholding state order requiring company to take natural gas at fixed prices although 90 percent of gas went out of state); Gorum v. Okla. Liquefied Petroleum Gas Bd., 235 F. Supp. 406 (W.D. Okla. 1964) (upholding state prohibition on nonresidents storing or dispensing gas).

Regulations were invalidated in FPC v. Corp. Comm'n of Okla., 362 F. Supp. 522 (W.D. Okla. 1973), affd, 415 U.S. 961 (1974) (invalidating state orders fixing minimum well-head prices on natural gas from wells that moves in intra- and interstate commerce). In Sarge v. Jones, 225 U.S. 501, 524 (1912), the Court stated that "the State cannot, under cover of executing its police powers undertake what amounts essentially to a regulation of interstate commerce, or impose a direct burden upon that commerce." See also, Polar Ice Cream \& Creamery Co. v. Andrews, 375 U.S. 361 (1964) (invalidating state regulation which would have barred interstate milk from a large part of the Florida milk market); Southern Pac. v. Arizona ex rel. Sullivan, 325 U.S. 761 (1945) (invalidating state law regulating length of interstate trains).

105. Mont. Rev. Codes ANN. \$§ 15-35-101 to 111 (1979).

106. Commonwealth Edison Co. v. Montana, 49 U.S.L.W. 4957 (1981). 
that the tax does not discriminate against interstate commerce. ${ }^{107}$

On the other hand, in Maryland $v$. Louisiana, ${ }^{108}$ the commerce clause limited the state's taxing power. Louisiana was found to lack sovereignty over much of its offshore property, which is rich in oil and gas. ${ }^{109}$ While Louisiana producers must pay a severance tax on natural gas, Louisiana could not tax offshore producers of natural gas. This created an economic disparity, to which Louisiana responded by enacting a tax on the first use of gas in the state. ${ }^{10}$ The Court found the tax unconstitutional on the ground that it impermissibly discriminated against interstate commerce. ${ }^{111}$

2. The Privileges and Immunities Clause and Interstate Comity. The "privileges and immunities" clause in article IV of the Constitution is sometimes known as the comity clause ${ }^{12}$ since its purpose is to ensure comity and courtesy among the states. Although this clause has been sparingly applied by the Court, at times it has been invoked with respect to natural resources and state and local taxation. ${ }^{113}$ The few cases actually decided under the privileges and immunities clause dealing with natural resources and wildlife reject the theory of state ownership of such resources. ${ }^{114}$ These cases seem to stand for the proposition that a state has governmental power to regulate the exploitation of resources so long as the regulations do not discriminate against out-of-state residents.

In Hicklin v. Orbeck, "15 an Alaskan statute known as "Alaska Hire"116 was challenged as violating the privileges and immunities clause by a group of nonresidents seeking jobs in the Alaskan resource industry. The Supreme Court held that the Alaska Hire was unconstitutional under the privileges and immunities clause, since the State made no showing that the nonresidents were a "peculiar source of evil" which Alaska Hire was intended to remedy, that is, Alaska's high unemploy-

107. 49 U.S.L.W. 4960 . Under the test set forth in Complete Auto Transit, Inc. v. Brady, 430 U.S. 274, 279 (1977), a state tax does not offend the commerce clause if it "is applied to an activity with a substantial nexus with the taxing state, is fairly apportioned, does not discriminate against interstate commerce, and is fairly related to the services provided by the state." However the state court in Dayton Power \& Light Co. v. Lindley, 58 Ohio St. 2d 465, 391 N.E. 2d 716 (1979), declared a severance tax on coal mined in Ohio to be unconstitutional. The tax favored sulphur-rich Ohio coal by imposing a lower tax rate on high sulphur coal, and thus constituted an impermissible burden on interstate commerce.

108. 49 U.S.L.W. 4562 (1981). See generally, Morgan and Olson, Nonneutral Features of Energy Taxation, 20 Nat. Resources J. 853 (1980); Comment, The Louisiana First-Use Tax: Does It Violate the Commerce Clause 53 Tulane L. REV. 1474 (1979); Note, The Effect and Validity of Stale Taxation of Energy Resources, 58 WASH. U. L. Q. 345 (1980); Note, First Use Tax, 31 LA. CoAstal L. REP. 1 (1978).

109. Comment, The Louisiana First-Use Tax, supra note 108, at 1474-80.

110. La. Rev. Stat. ANn. 47; 1301 (A) (West Supp. 1980).

111. 49 U.S.L.W. at 4566 .

112. U.S. ConST., art. IV, $\$ 2, \mathrm{cl}$. 1. This clause provides that "the Citizens of each State shall be entitled to all Privileges and Immunities of Citizens in the several States." See generally, NowAK, supra note 82, at 275-79.

113. For a discussion of state taxation, see notes 92-111 supra and accompanying text.

114. See, e.g., Toomer v. Witsell, 334 U.S. 385 (1948) (invalidating a state law requiring license fees to be paid by nonresidents at a much higher rate than by residents).

115. 437 U.S. 518 (1978).

116. Alaska STAT. $\$ \$ 38.40 .010$ to .090 (1977). The key provision of "Alaska Hire" required that "all oil and gas leases, easements or right-of-way permits for oil or gas pipeline purposes, unitization agreements, or any renegotiation of any of the preceding to which the state is a party" must contain a provision that "qualified Alaska residents" be hired in preference to nonresidents. 
ment. ${ }^{117}$

3. The Supremacy Clause and Federal Preemption of State Regulation. The supremacy clause $^{118}$ operates to preempt state legislation where there is actual conflict between the state and federal laws. ${ }^{119}$ Because of the broad federal regulatory schemes dealing with energy that have been enacted by Congress, the supremacy clause is a powerful tool for challenging state legislation in the field of energy. ${ }^{120}$

The Court has recently adopted a strict interpretation of conflict and will invalidate state legislation only where there is clear evidence of congressional intent to preempt state regulation. ${ }^{121}$ Nonetheless, the supremacy clause and the doctrine of federal preemption continue to be a significant restraint on state regulation of oil and gas.

In Arizona Public Service Co. v. Snead ${ }^{122}$ the Court invalidated a New Mexico tax on energy. The tax applied to all utility companies generating electricity within the state. For electricity sold at retail within New Mexico, this tax could be credited against the New Mexico gross receipts tax, but where the electricity was sold in other states, no such credit was available. Because the tax discriminated against out-of-state consumers, the Court found that the tax violated a federal statute prohibiting such discrimination, and invalidated the tax under the supremacy clause. ${ }^{123}$

In Mobil Oil Corp. v. Tully ${ }^{124}$ a federal district court held that a New York statute, ${ }^{125}$ imposing a gross receipts tax on oil companies while not allowing them to "pass" the tax on in increased sales prices was preempted by the Emergency Petroleum Allocation Act ${ }^{126}$ and the Mandatory Petroleum Price Regulations. ${ }^{127}$ The state statute was therefore held invalid under the supremacy clause.

117. 437 U.S. at 526. The Court continued that even if the State's showing was accepted as sufficient to indicate that nonresidents were a "peculiar source of evil," the statute still did not pass constitutional muster, since "the discrimination the Act works against nonresidents does not bear a substantial relationship to the particular 'evil' they are said to present." Id. at 527.

118. U.S. CONST., art. VI, cl. 2.

119. See generally, NowAK, supra note 82 , at 267-70.

120. See, e.g., FPC v. Corp. Comm'n of Okla., 362 F. Supp. 522, 535-41 (W.D. Okla. 1973), affd, 415 U.S. 961 (1974) (invalidating state regulations fixing minimum well-head prices of natural gas on grounds that the regulations conflict with rates fixed by the FPC under the Natural Gas Act); Natural Gas Pipeline Co. v. Corp. Comm'n of Okla., 349 U.S. 44 (1955) per curiam (invalidating state regulations fixing minimum price for natural gas after production and gathering has ended on grounds that such sales are to be regulated exclusively by the FPC).

121. In New York State Dep't of Social Serv. v. Dublino, 413 U.S. 405, 413 (1973), the Court held that despite the similarity of the provisions, the New York Work Rules were not preempted by the 1967 amendments to the Social Security Act, specifically the Work Incentive Program. Justice Powell quoted Schwartz v. Texas, 344 U.S. 199, 203-03: "If Congress is authorized to act in a field it should manifest its intention clearly. . . [ $t$ ]he exercise of Federal supremacy is not likely to be presumed.

122. 441 U.S. 141 (1979).

123. The Tax Reform Act of 1979 included a provision prohibiting discriminatory state taxes on electricity. 15 U.S.C. $§ 391$ (1979).

124. 499 F. Supp. 888 (N.D.N.Y. 1980).

125. N.Y. Tax Law $\$ 182(12)$ (a) (McKinney 1980).

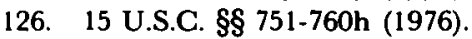

127. 10 C.F.R. $\$ 212.81-85$ (1981). 
III

\section{CONCLUSION}

With the battle lines drawn and the constitutional arenas defined, some observations regarding the positions of the opponents in each country are possible. An important basic difference between the U.S. Constitution and the Canadian Constitution is the provision for local authority. While the provinces have certain explicitly enumerated powers, states have a general reservation of all powers not specifically delegated to the federal government. While in theory this may give states greater flexibility than provinces in attempting to assert control over natural resources, it deprives them of a "bottom line" with which to resist ever-broadening interpretations of the federal government's enumerated powers.

On the other hand, although provinces have the advantage of certain affirmative powers, they must, when asserting control over resources, satisfy the dual burden of showing not only that the action taken is outside federal authority, but also that the action is an authorized exercise of provincial authority. Thus, the tactics they employ must be more finely tuned than state tactics.

Whether one constitutional system or the other is ultimately more favorable to either local or national government remains to be seen. Because there are so many factors at work beyond the broad legal confines of the debate, constitutional considerations may not be the most influential in shaping any final resolution. What is assured, however, is that the struggle for control over natural resources is far from being resolved. In both Canada and the United States, the federal government has been expanding its control over natural resources to include matters traditionally considered to be exclusively local in nature. This expansion has set the stage for continued confrontation in both nations as to the ultimate distribution of governmental authority over natural resources. 
